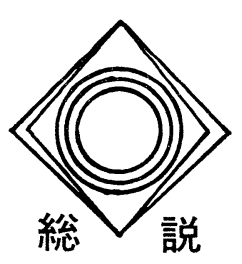

エネルギー有效利用からみた

\author{
石炭変換プロセスの評価 $(\mathbb{V})$ \\ 一液化プロセスシステムの \\ エネルギー・エクセルギー解析一
}

-1982. 3. 23 受理一

$\begin{array}{llll}\text { 東京理科大学 } & \text { 西 } \text { 田 直 } \begin{array}{c}\text { 矩* } \\ \text { 東京工業大学 }\end{array} \text { 石 } \text { 田 } & \text { 愈** }\end{array}$

\section{1. はじめに}

前回1) では，まず石炭のエンタルピーとエントロピ 一の推算法について概観し, ついで石炭ガス化に和け る目的プロセスの設定法などについて論じた後, ガス 化のモデルプロセスのエクセルギー解析例を示した。

今回は, 石炭の液化プロセスシステムのエネルギー ・エクセルギー解析を展開していく。そこで 2. で石 炭液化油のエンタルピーとエントロピーの值ならびに その推算法について触れた後, 液化のモデルプロセス システムのエクセルギー解析例を示し, 3. で現在米国 で開発中の主要な液化プロセスのエンタルピーおよび エクセルギーの絶対量に基づいた効率について論じ,

4. で直接液化法および間接液化法のプロセスから得ら れる液化生成油の最終用途とその消費を考慮した場合 の一次エネルギーから製品の最終消費に至るエネルギ 一効率の評価例を紹介する。

\section{SPEEDを用いた石炭液化プロセスのエク セルギー解析}

石炭液化油は非常に多種多様な分子から成る混合物 である。そこで鈴木ら 2 は，原子団寄与の考方方を利 用して, 液化油を構成している主要な原子団の分布を 推測し元素組成抢よび沸点のみから液化油の生成エン タルピーと絶対エントロピーを推算する式を提案して いる。そして，それ基づき図 1 注) 示す石孷液化モ デルプロセスについて SPEED (Structured Process Energy-Exergy-Flow Diagram) によるエクセルギ 一計算を行っている。

この図1では, 石炭液化プロセスのターゲットとし て, 石炭に水素が作用して液化油を生成する過程を選

* 工学部経営工学科

** 資源化学研究所

東京都新宿区神楽坂 $1-3$ 横浜市緑区長津田 4259
び，それを(1)石炭と溶剤の混合，(2)スラリーの予熱, (3)水素化分解，(4)液化油の分離，の各サブターグッ卜 に分割して，それぞれのエンタルピー変化とエクセル ギー変化を算出している。

サブターゲット(1)では, 固体と液体との単なる物理 的混合とみなして， $\Delta \mathrm{H}$ と $\Delta \mathrm{S}$ は 0 としている。

サブターダット(2)の予熱では, スラリーの昇温と水 素の昇温ならびに等温での石炭の水添反応とに細分し ている。これらは実際の予熱器内では同時に進行する が，このように分離して考光ると，この段階での反応 が若干の発熱反応で, 熱源型 $(\Delta \mathrm{H}<0, \Delta \varepsilon<0)$ の反応 になって和り,この発生した熱はスラリ一の予熱に利 用される。残りの必要な熱を $750^{\circ} \mathrm{C}$ の熱源を利用して 与光ると, この熱源に対する $\Delta \varepsilon$ は $-7.28 \mathrm{kcal}$ であ るから，このサブシステムに和けるエクセルギー損失 は, $-(-7.28+3.15)=4.13 \mathrm{kcal}$ となる。

サブターゲット(3)の水素化分解反応も，スラリーの 昇温と水素の昇温ならびに等温での水素化分解反応に 細分している。水素化分解は予熱段階の水添反応と同 様，熱源型のプロセスとなっている。この段階での熱 損失を $2.43 \mathrm{kcal}$ と拈くと，サブシステム(3)におけるエ クセルギー損失は， $-(-2.82-0)=2.82 \mathrm{kcal}$ 之計算 される。

図1の(4)の分離では, 液混合物をナフサ, 中質油, 重質油に分離するのに必要なエクセルギーを算出して いる。この部分を蒸留プロセス等に置さ換光, さらに 加圧や熱回収の過程を考慮することによって, 石炭液 化プロセス内でのェネルギー変化, エクセルギー変化 を検討していくことができる。

注) 図中の記号等の説明については前回のを参照さ れたい。 


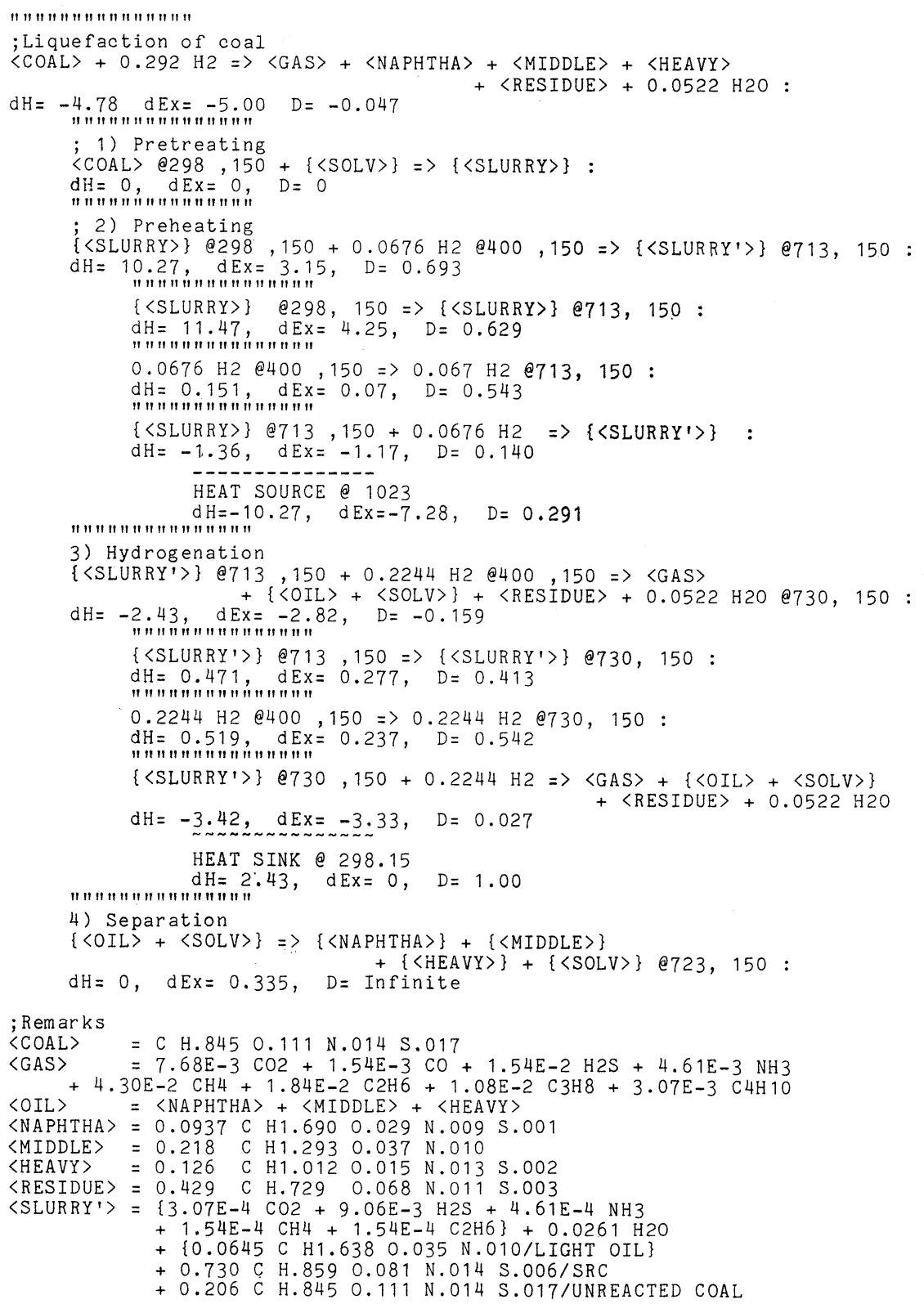

図 1 石炭の液化モデルプロセスシステムの SPEED

表 1 モデル液化プロセスの石炭および液化生成物の $\Delta \mathbf{H}_{\mathbf{f}}^{\circ}$ と $\mathbf{S}^{\circ}$ の推算值

$\langle\mathrm{COAL}\rangle\langle$ NAPHTHA $\rangle\langle$ MIDDLE $\rangle\langle$ HEAVY $\rangle\langle$ RESIDUE $\rangle\langle\mathrm{LIGHT}$ OIL $\rangle\langle$ SRC $\rangle$

\begin{tabular}{lrrrrrrr}
\hline$\Delta \mathrm{H}_{\mathrm{f}}^{\circ}[\mathrm{Kcal} / \mathrm{mol}-\mathrm{C}]$ & -2.51 & -6.38 & -3.37 & 0.12 & -0.03 & -6.19 & -1.48 \\
$\mathrm{~S}^{\circ}[\mathrm{Cal} / \mathrm{mol}-\mathrm{C} \mathrm{K}]$ & 4.25 & 14.36 & 9.37 & 5.26 & 3.94 & 13.84 & 4.11 \\
\hline
\end{tabular}

なお，表 1 はこのモデル液化プロセスのエクセルギ 一解析で用いた石炭および液化生成物のエンタルピー
拉よびェントロピーを鈴木らの推算法で求めた值であ る。 


\section{3. 主要な石炭直接液化プロセスのエネルギ 一効率}

米国で開発が進められているいくつかの直接液化プ ロセスについては, 想定される商業プラントの概念設 計のデータが公表されている。ここではこれらのデー 夕に基づいて，代表的な直接液化プロセスである SRC 一I プロセス，SRC-II プロセス拉よびH-Coalプロセ スのエネルギー効率の評価を行う。

\section{1 評価プロセスの概要}

3.1.1 SRC (溶剤精製炭)を主製品とするプロセス SRC-I プロセスの開発を進めている ICRC (International Coal Refining Company) 飞参加して いる Catalytic 社が EPRI の要請に基づいて SRC を主製品とする概念的な商業プロセスのフローを提案 している3゙。そこでは，以下洒すような 4 つのプロ セスを提案している。

1.万過法を用いた SRC-I プロセス

2. CSD 法を用いた SRC-I プロセス

3. Short Residence Time 2 段液化プロセス

4. CSD 法拈よび2 次水添工程を併った Short Residence Time プロセス

第1のプロセスは, Wilsonville, Ala. のパイロッ トプラントで開発が進められている SRC-I プロセス 飞挆いて石炭液化生成スラリーの固液分離に加圧ろ過
装置を用いたプロセスのフローに基づくものである。 第 2 のプロセスは, 固液分離工程に Kerr-McGee 社 の開発した CSD (Critical Solvent Deashing) 装置 を採用した SRC-I プロセスである。

第 3 抢よび第 4 のプロセスは, 一段目の液化を短時 間で行った後, 灰分を含む液化残渣を固液分離工程で 除さ，さらに 2 段目の液化工程で水素ガスを用いて水 添を行って低硫黄の SRC を主製品として生産するプ ロセスである。一段目の液化の反応条件は, 約 $30 \mathrm{~atm}$, $440{ }^{\circ} \mathrm{C}$ で水素ガスは用いていない。スラリ一滞留時間は 約 4 分である。このように一段目の液化を短時間で行 らプロセスは一般に Short Residence Time (SRT) あるいは Short Contact Time (SCT) プロセスとい われ，水素消費量の低減を目的としたプロセスである。 第 3 のSRT 2 段液化プロセスでは，ろ過法を固液分 離工程に採用している。固液分離工程で残渣を除かれ た生成油は 2 段目の液化工程で, 水素ガス存在下, 113atm， $474^{\circ} \mathrm{C}$ の反応条件で水添が行わ和, 低硫黄の SRC を生産する。

一方，第4の SRT-SRC プロセスにおいては，一 段目の液化工程で水素供与性のプロセス溶剂 (hydrogenated Process Solvent)を用いたSRT プロセス を想定している。一段目の液化工程からの生成油スラ リ一は，CSD プロセスに怙いて脱灰され，SRCが生

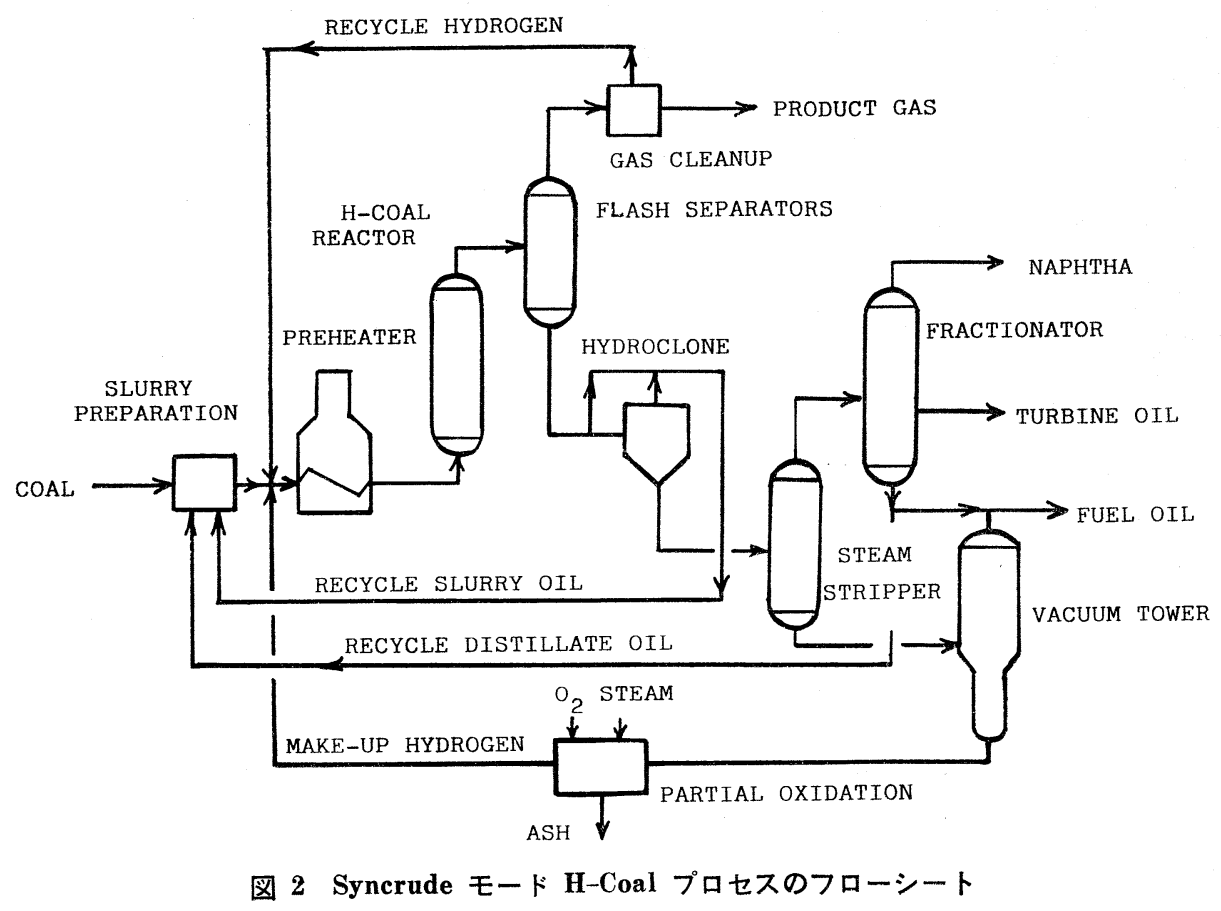


産される。さらに, この SRC は軽質分と重質分の SRC 飞分留され, 軽質 SRC は, 沸騰床型の反応器 に拈いて, 103atm, $400^{\circ} \mathrm{C}$ の反応条件で水添が行われ る。この水添された低硫黄の軽質 SRC は, 重質 SRC と混合されて, 製品 SRC となる。

\section{$3.1 .2 \mathrm{H}$-Coal プロセス}

Flour Engineers and Constructors 社は, EPRI の要請に基づいて Syncrude モード H-Coal プロセ スの $14,448 \mathrm{t} / \mathrm{d}$ (short ton)商業プラントの概念設計 を行っている4)。概念設計は，歴青炭のIllinois No.6 炭および亜歷青炭の Wyodak 炭を原料とする 2 つの 場合について行って频り, 因2 はそのプロセスのフロ ーシートである。ここでは, Illinois 炭を原料とする プロセスを第 5 , Wyodak 炭を原料とするプロセスを 第 6 番目の評価対象プロセスとする。

\subsubsection{SRC-II プロセス}

ICRCに参加している Air Products and Chemicals 社は, SRC-I プロセスを基本としたいくつ かの想定される商業プロセスのフローを提案してい る5っ。たプロセスの経済性の比較を目的として, SRC ーII プロセスの想定商業プロセスのフローも提案して いる。ここでは, この SRC-II プロセスの原料和よび 製品に関するデータに基づいてェネルギー解析を行 い,これを第 7 番目の評価プロセスとする。

3.2 評価プロセスの石炭処理量技よび製品生産量 各評価プロセスの原料石炭の処理量を表 2 に示す。 な拉，No.1〜4の SRC プロセスのフローはいずれも grass roots プラントル基づいている。従って, ニー ティリティ（電力，スチームなど）はすべてプラント 内で自給して和り, 原料石炭の一部梳石炭化工程以 外䚾利用されているプロセスもある。同様に, №. 5 および6の H-Coal プロセスも grass roots プラン トの設計に基づいている。ただし， No. 7 の SRC-II プ ロセスでは, プラント内の所要電力は, 外部より購入
表 2 評価プロセスの原料石炭処理量

\begin{tabular}{clc}
\hline $\begin{array}{c}\text { Process } \\
\text { No. }\end{array}$ & \multicolumn{1}{c}{ Process } & $\begin{array}{c}\text { Feed Coal to Plant } \\
\text { t/d (MAF Basis) }\end{array}$ \\
\hline 1 & SRC with Filtration & 9772.0 \\
2 & SRC with CSD & 9209.2 \\
3 & Two-stage SRT SRC & 9992.0 \\
4 & SRT-SRC & 8549.4 \\
5 & H-Coal (Illinois) & 11598.6 \\
6 & H-Coal (Wyodak) & 12179.2 \\
7 & SRC-II & 24385.5 \\
\hline
\end{tabular}

することを想定した設計になっている。表 3 は各プロ セスからの製品と呑の生産量を示したものである。 №.1〜4の SRC プロセスでは, grass roots プラン トということで, 液化工程で発生したガスは, すべて ニーティリティ生産のための然料などに利用されてい るため, 製品として表われていない。な拉，これらの すべてのプロセスでは, 副製品としてフェノール類, アンモニア, 硫黄などが得られるが, エネルギー効率 の評価治抢いては, 目的製品とせず計算から除外乙 た。

3.3 絶対量としてのエンタルピー, エクセルギ 一の計算方法

各石炭液化プロセスの効率の評価は, 後述するよう に, エンタルピーおよびェクセルギーの絶対量に基づ いて行う。そのためには, 各液化プロセスシステムに ついて, 入力されたすべてのエネルギー源となる物質 (石炭, 電力など), および目的物 (製品)のエンタル ピー, エクセルギーの絶対量を求めな汀ればならな い。石炭のエンタルピーの絶対量については, 第 3 報 で述べた方法，すなわら鈴木ら ${ }^{6}$ の提案した推算式を 使って, まず石炭の元素分析值传基ついて $\Delta \mathrm{H}_{\mathrm{f}}{ }^{\circ}$ を求 め，それから完全然燒したときの $\Delta \mathrm{H}_{\mathrm{c}}{ }^{\circ}$ を求める。亦 た室温で固体である SRC (溶剤精製炭) のエンタルピ

表 3 評価プロセスの製品とその生産量

\begin{tabular}{cl}
$\begin{array}{c}\text { Process } \\
\text { No. }\end{array}$ & \multicolumn{1}{c}{ Products and their Production Rate } \\
{$[t / d]$}
\end{tabular}


一についても, 同様な方法で計算した。各種製品液化 油については，元素分析值および平均沸点に基つきき, 鈴木ら2の提案している推算式を用いて $\Delta \mathrm{H}_{\mathrm{f}}{ }^{\circ}$ を求め, それから，完全然焼したときの $\Delta \mathrm{H}_{\mathrm{e}}{ }^{\circ}$ を求めた。

石炭および製品液化油のエクセルギーの絶対量は以 下のようにして求めた。

石炭および液化油を $\mathrm{CH}_{\mathrm{x}} \mathrm{O}_{\mathrm{y}} \mathrm{N}_{\mathrm{z}} \mathrm{S}_{\mathrm{w}}$ のように炭素 1 mol 当りの值を採り, $1 \mathrm{~mol}-\mathrm{C}$ の石炭あるいは液化油 とする。このとき $1 \mathrm{~mol}-\mathrm{C} の$ 石炭和よび液化油のエク セルギー， $\varepsilon^{\circ} \mathrm{CHxOyNz}_{\mathrm{N} w}$ ：は以下のように表わされる。

$$
\begin{aligned}
\varepsilon^{\circ} \mathrm{CHxOyNzS}=\varepsilon_{\mathrm{C}}{ }^{\circ} & +\frac{1}{2} \mathrm{x} \varepsilon_{\mathrm{H} 2}{ }^{\circ}+\frac{1}{2} \mathrm{y} \varepsilon_{\mathrm{O} 2}{ }^{\circ}+\frac{1}{2} z_{\mathrm{N} 2}{ }^{\circ} \\
& +\mathrm{w} \varepsilon_{\mathrm{S}}{ }^{\circ}+\Delta \mathrm{G}_{\mathrm{f}}{ }^{\circ} \mathrm{CHxOyNzSw}
\end{aligned}
$$

$\varepsilon_{\mathrm{C}}^{\circ}, \varepsilon_{\mathrm{H} 2}^{\circ}, \varepsilon_{\mathrm{O} 2}^{\circ}, \varepsilon_{\mathrm{N} 2}^{\circ}$ 尔よび $\varepsilon_{\mathrm{S}}^{\circ}$ は, それぞれ, C, $\mathrm{H}_{2}, \mathrm{O}_{2}, \mathrm{~N}_{2}$ および $\mathrm{S}$ に対する化学エクセルギーで, 25 ${ }^{\circ} \mathrm{C}, 1 \mathrm{~atm}$ に対して，表4のように与兄られている7。

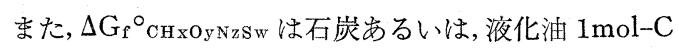
当りの生成自由エネルギーである。石炭あるいは液化 油の生成自由エネルギーについては, データがないの で, 以下のように推算した。

まず，石炭あるいは液化油の $\Delta \mathrm{H}_{\mathrm{f}}{ }^{\circ}$ 和よび絶対エン トロピー $\mathrm{S}^{\circ}$ を鈴木らの推算式によって求めた。つぎ に, これらの $\Delta \mathrm{H}_{\mathrm{f}}{ }^{\circ}$ 和よび $\mathrm{S}^{\circ}$ を用いて, 石炭あるい は, 液化油の生成自由エネルギーを以下の関係から求 めた。
表 4 基本物質の化学エクセルギー7)

\begin{tabular}{ccc}
\hline Substance & State & $\begin{array}{c}\varepsilon^{\circ}(298 \mathrm{~K}, 1 \text {. 0atm }) \\
(\mathrm{KJ} / \mathrm{Kmol})\end{array}$ \\
\hline $\mathrm{N}_{2}$ & $\mathrm{~g}$ & 599 \\
$\mathrm{O}_{2}$ & $\mathrm{~g}$ & 3902 \\
$\mathrm{H}_{2}$ & $\mathrm{~g}$ & 235400 \\
$\mathrm{C}$ & graphite & 410780 \\
$\mathrm{~S}$ & crystalline & 584730 \\
\hline
\end{tabular}

$$
\begin{aligned}
\Delta \mathrm{G}_{\mathrm{f}}{ }^{\circ}, \mathrm{CHxOyNzSw}= & \Delta \mathrm{H}_{\mathrm{f}}{ }^{\circ} \mathrm{CHxOyNzSw} \\
& -\mathrm{T}_{\mathrm{o}} \Delta \mathrm{S}_{\mathrm{f}}{ }^{\circ} \mathrm{CHxOyNzSw} \\
= & \Delta \mathrm{H}_{\mathrm{f}}{ }^{\circ} \mathrm{CHxOyNzSw} \\
& -\mathrm{T}_{\circ}\left(\mathrm{S}^{\circ} \mathrm{CHXYNzSw}-\mathrm{S}_{\mathrm{c}}{ }^{\circ}-\frac{1}{2} \mathrm{xS}_{\mathrm{H} 2}{ }^{\circ}\right. \\
& \left.-\frac{1}{2} \mathrm{yS}_{\mathrm{O} 2}{ }^{\circ}-\frac{1}{2} \mathrm{zS}_{\mathrm{N} 2}{ }^{\circ}-\mathrm{wS}_{\mathrm{s}}{ }^{\circ}\right)
\end{aligned}
$$

$\mathrm{S}_{\mathrm{C}}{ }^{\circ}, \mathrm{S}_{\mathrm{H} 2}{ }^{\circ}, \mathrm{S}_{\mathrm{O} 2}{ }^{\circ}, \mathrm{S}_{\mathrm{N} 2}{ }^{\circ}$ および $\mathrm{S}_{\mathrm{S}}^{\circ}$ はそれぞれ，C， $\mathrm{H}_{2}, \mathrm{O}_{2}, \mathrm{~N}_{2}, \mathrm{~S}$ の絶対エントロピーである。

\section{4 結果の概要}

表 5 は原料石炭の元素分析值と $1 \mathrm{~mol}-\mathrm{C}$ 当りの分子 量である。この元素分析值に基ついて求めた，各石炭 の $1 \mathrm{~mol}-\mathrm{C}$ 当りの $25^{\circ} \mathrm{C}, 1 \mathrm{~atm}$ 基準の $\Delta \mathrm{H}_{\mathrm{f}}{ }^{\circ}, \mathrm{S}^{\circ}, \Delta \mathrm{G}_{\mathrm{f}}{ }^{\circ}$, $\Delta \mathrm{H}_{\mathrm{C}}{ }^{\circ}, \varepsilon^{\circ}$ を表 6 に示す。また, 各液化プロセスの製品 についても, 元素分析值, 平均沸点に基ついてこれら の熱力学データを求めた。ここでは, 紙数も限られて いるので, SRT-SRC プロセスの製品および H-Coal

表 5 原料石炭の元素分析值と $1 \mathrm{~mol}-\mathrm{C}$ 当りの分子量

\begin{tabular}{clcccccc}
\hline $\begin{array}{c}\text { Process } \\
\text { No. }\end{array}$ & \multicolumn{2}{c}{ Coal Type } & \multicolumn{2}{c}{ Ultimate Analysis, \%wt MAF Basis } & \multicolumn{2}{c}{ Molecular } \\
& & $\mathrm{C}$ & $\mathrm{H}$ & $\mathrm{N}$ & $\mathrm{S}$ & $\mathrm{O}$ & Weight of 1mol-C \\
\hline 5 & Illinois No, & 78.83 & 5.55 & 1.66 & 3.92 & 10.04 & 15.2360 \\
$1,2,3$ & Kentucky No.9/14 & 79.70 & 5.46 & 1.60 & 3.24 & 10.00 & 15.0704 \\
4 & Kentucky No.9/14 & 78.60 & 5.65 & 1.52 & 3.78 & 10.45 & 15.1330 \\
7 & Kentucky No.9 & 78.80 & 5.58 & 1.56 & 3.79 & 10.27 & 15.2435 \\
6 & Wyodak & 71.65 & 5.31 & 1.13 & 1.23 & 20.68 & 16.7628 \\
\hline
\end{tabular}

表 6 原料石炭の $\Delta \mathbf{H}_{\mathbf{f}^{\circ}}, \mathbf{S}^{\circ}, \Delta \mathbf{G}_{\mathbf{f}}{ }^{\circ},-\Delta \mathbf{H}_{\mathbf{c}}{ }^{\circ}, \varepsilon^{\circ}$ の推算值

\begin{tabular}{clccccc}
\hline $\begin{array}{c}\text { Process } \\
\text { No. }\end{array}$ & \multicolumn{1}{c}{ Coal Type } & $\begin{array}{c}\Delta \mathrm{H}_{\mathrm{f}}{ }^{\circ} \\
{[\mathrm{Kcal} / \mathrm{mol}-\mathrm{C}]}\end{array}$ & $\begin{array}{c}\mathrm{S}^{\circ} \\
{[\mathrm{Cal} / \mathrm{mol}-\mathrm{C} \cdot \mathrm{K}]}\end{array}$ & $\begin{array}{c}\Delta \mathrm{G}_{\mathrm{f}}{ }^{\circ} \\
{[\mathrm{Kcal} / \mathrm{mol}-\mathrm{C}]}\end{array}$ & $\begin{array}{c}-\Delta \mathrm{H}_{\mathrm{c}}{ }^{\circ} \\
{[\mathrm{Kcal} / \mathrm{mol}-\mathrm{C}]}\end{array}$ & $\begin{array}{c}\varepsilon^{\circ} \\
{[\mathrm{Kcal} / \mathrm{mol}-\mathrm{C}]}\end{array}$ \\
\hline 5 & IllinoisNo. 6 & -1.87 & 4.17 & 2.06 & 122.16 & 126.49 \\
$1,2,3$ & Kentucky No. $9 / 14$ & -1.66 & 4.14 & 2.15 & 121.36 & 125.47 \\
4 & Kentucky No.9/14 & -2.15 & 4.20 & 1.87 & 122.43 & 126.71 \\
7 & Kentucky No.9 & -1.99 & 4.18 & 1.97 & 122.17 & 126.45 \\
6 & Wyodak & -6.88 & 4.91 & -2.14 & 117.77 & 121.86 \\
\hline
\end{tabular}


表 7 SRT-SRC プロセスの製品の元素分析値と 熱力学定数の推算值

\begin{tabular}{ccccr}
\hline & Light Oil & Process Solvent & SRC \\
\hline Ultimate & \multicolumn{1}{c}{$\mathrm{C}$} & 79.41 & 86.43 & 83.24 \\
Analysis & $\mathrm{H}$ & 15.97 & 9.49 & 5.96 \\
wt $\%$ & $\mathrm{~N}$ & 0.47 & 0.74 & 1.58 \\
& $\mathrm{~S}$ & 0.00 & 0.19 & 0.87 \\
$\mathrm{O}$ & 4.20 & 3.15 & 8.35 \\
$\mathrm{Cut}\left[{ }^{\circ} \mathrm{F}\right]$ & $\mathrm{IBP} / 450$ & $450 / 780$ & $780^{+}$ \\
$\Delta \mathrm{H}_{\mathrm{f}}{ }^{\circ}[\mathrm{Kcal} / \mathrm{mol}-\mathrm{C}]$ & -12.69 & -3.02 & -1.18 \\
$\mathrm{~S}^{\circ}[\mathrm{Cal} / \mathrm{mol}-\mathrm{C} \cdot \mathrm{K}]$ & 25.11 & 9.68 & 4.06 \\
$\Delta \mathrm{G}_{\mathrm{f}}{ }^{\circ}[\mathrm{Kcal} / \mathrm{mol}-\mathrm{C}]$ & -8.29 & 0.84 & 2.66 \\
$-\Delta \mathrm{H}_{\mathrm{c}}{ }^{\circ}[\mathrm{Kcal} / \mathrm{mol}-\mathrm{C}]$ & 163.22 & 135.78 & 122.29 \\
$\varepsilon^{\circ}[\mathrm{Kcal} / \mathrm{mol}-\mathrm{C}]$ & 157.32 & 135.95 & 125.42 \\
\hline
\end{tabular}

表 8 H-Coal プロセス (Illinois ケース) の製品の 元素分析値と熱力学定数の推算値

\begin{tabular}{l|cccc}
\hline & Naphtha & Turbine Fuel & Boiler Fuel \\
\hline Ultimate & $\mathrm{C}$ & 85.34 & 88.35 & 89.42 \\
Analysis & $\mathrm{H}$ & 13.79 & 10.11 & 8.56 \\
$\mathrm{wt} \%$ & $\mathrm{~N}$ & 0.24 & 0.47 & 0.63 \\
& $\mathrm{~S}$ & 0.07 & 0.08 & 0.08 \\
$\mathrm{O}$ & 0.56 & 0.99 & 1.31 \\
$\mathrm{Cut}\left[{ }^{\circ} \mathrm{F}\right]$ & $\mathrm{c}_{4} / 350$ & $350 / 600$ & $500 / 800$ \\
$\Delta \mathrm{H}_{\mathrm{f}}{ }^{\circ}[\mathrm{Kcal} / \mathrm{mol}-\mathrm{C}]$ & -7.38 & -2.77 & -0.93 \\
$\mathrm{~S}^{\circ}[\mathrm{Cal} / \mathrm{mol}-\mathrm{C} \cdot \mathrm{K}]$ & 16.92 & 9.58 & 6.80 \\
$\Delta \mathrm{G}_{\mathrm{f}}{ }^{\circ}[\mathrm{Kcal} / \mathrm{mol}-\mathrm{C}]$ & -3.00 & 1.22 & 2.88 \\
$-\Delta \mathrm{H}_{\mathrm{c}}{ }^{\circ}[\mathrm{Kcal} / \mathrm{mol}-\mathrm{C}]$ & 152.46 & 137.88 & 132.11 \\
$\varepsilon^{\circ}[\mathrm{Kcal} / \mathrm{mol}-\mathrm{C}]$ & 149.38 & 137.81 & 133.20 \\
\hline
\end{tabular}

表 9 H-Coal プロセス (Wyodak ケース) の 製品の元素分析値と熱力学定数の推算値

\begin{tabular}{lcccc} 
& & Naphtha & Turbine Fuel & Boiler Fuel \\
\hline Ultimate & $\mathrm{C}$ & 84.66 & 86.97 & 88.40 \\
Analysis & $\mathrm{H}$ & 13.97 & 11.39 & 9.41 \\
wt $\%$ & $\mathrm{~N}$ & 0.10 & 0.22 & 0.46 \\
& $\mathrm{O}$ & 0.02 & 0.03 & 0.03 \\
$\mathrm{Cut}\left[{ }^{\circ} \mathrm{F}\right]$ & 1.25 & 1.39 & 1.70 \\
$\Delta \mathrm{H}_{\mathrm{f}}{ }^{\circ}[\mathrm{Kcal} / \mathrm{mol}-\mathrm{C}]$ & -8.01 & -4.57 & -2.15 \\
$\mathrm{~S}^{\circ}[\mathrm{Cal} / \mathrm{mol}-\mathrm{C} \cdot \mathrm{K}]$ & 17.68 & 12.60 & 8.79 \\
$\Delta \mathrm{G}_{\mathrm{f}}{ }^{\circ}[\mathrm{Kcal} / \mathrm{mol}-\mathrm{C}]$ & -3.64 & -0.56 & 1.68 \\
$-\Delta \mathrm{H}_{\mathrm{c}}{ }^{\circ}[\mathrm{Kcal} / \mathrm{mol}-\mathrm{C}]$ & 153.22 & 142.79 & 135.24 \\
$\approx^{\circ}[\mathrm{Kcal} / \mathrm{mol}-\mathrm{C}]$ & 149.88 & 141.54 & 135.56 \\
\hline
\end{tabular}

プロセスの製品の推算結果のみを表 7 9 と示す。

以上の計算結果に基づき, 各液化プロ セスのェンタルピー抢よびェクセルギー の絶対量飞基づく効率を求める。ここ では, プロセスシステムの効率を以下の ように定義する。

$$
\begin{aligned}
& \eta_{1}=\frac{\text { 目的物のエンタルピ- }}{\begin{array}{c}
\text { システムルスってきた } \\
\text { エンタルピーの合計 }
\end{array}} \\
& r_{2}=\frac{\text { 目的物のエクセルギー }}{\text { システムに入ってきた }} \\
& \text { エクセルギーの合計 }
\end{aligned}
$$

システムに入ってきたエンタルピー特 よびエクセルギーは grass rootsプラン 卜の場合, 石炭の値を用いる。第 7 番目 の SRC-II プロセスでは，電力を外部か ら購入する設計になっているので，その 所要電力のエンタルピーおよびエクセル ギーも分母に加算される。目的物のエン タルピーおよびェクセルギーは, 製品の 值を用いる。

表10は各評価プロセスのエンタルピー 牤よびェクセルギー基準の効率 $\eta_{1}, r_{2}$ の 計算結果をまとめたものである。エンタ ルピー基準の効率もエクセルギー基準の 効率も0.64 0.71の範围にあることがわ かる。またエクセルギー基準の効率が約 1〜3\%低い程度で，ほとんど両者は接 近している。この理由は, 表 $6 \sim 9$ に示 したように，石炭就よび液化油のエンタ ルピー特よびェクセルギーが実質的はは 㴗とんど同じであり，それらの值を効率 の計算に用いているからである。

表10からわかるもらひとつの特徽は， H-Coal プロセスに和いて, 亜歴青炭の Wyodak 炭の場合の効率が, 歴青炭の Illinois 炭の場合よりも約10\%低いこと である。この差は, 表 3 からわかるよう に, Wyodak 炭の場合の製品の収率の低 さに帰因しているとい方ら。

また，SRC-II プロセスの効率が他の プロセスよりる優っている理由のひとつ は，他のプロセスが電力を自給する設計 になっているのに対して，このSRC-II プロセスの設計では, 電力を外部より購 
表 10 エンタルピーおよびェクセルギーの絶対量に基づいた石炭液化プロセスの効率

\begin{tabular}{|c|c|c|c|c|c|c|}
\hline \multirow{2}{*}{$\begin{array}{c}\text { Process } \\
\text { No. }\end{array}$} & \multicolumn{2}{|c|}{$\begin{array}{l}\text { Enthalpy Basis } \\
{[\mathrm{MMM} \mathrm{Kcal} / \mathrm{day}]}\end{array}$} & \multirow{2}{*}{$\begin{array}{c}\text { Thermal } \\
\text { Efficiency } \\
\eta_{1} \\
\end{array}$} & \multicolumn{2}{|c|}{$\begin{array}{l}\text { Exergy Basis } \\
{[\text { MMM Kcal/day] }}\end{array}$} & \multirow{2}{*}{$\begin{array}{c}\text { Exergy } \\
\text { Efficiency } \\
\qquad \eta_{2}\end{array}$} \\
\hline & input & output & & input & output & \\
\hline 1 & 78.69 & 53.55 & 0.681 & 81.36 & 54.71 & 0.673 \\
\hline 2 & 74.16 & 50.06 & 0.675 & 76.67 & 50.82 & 0.663 \\
\hline 3 & 80.46 & 52.30 & 0.650 & 83.19 & 53.53 & 0.644 \\
\hline 4 & 68.50 & 44.65 & 0.645 & 70.89 & 45.60 & 0.643 \\
\hline 5 & 92.99 & 62.54 & 0.673 & 96.29 & 62.14 & 0.645 \\
\hline 6 & 85.57 & 49.57 & 0.579 & 88.54 & 48. 98 & 0.553 \\
\hline 7 & 203. 75 & 145.56 & 0.714 & 210.65 & 143.76 & 0.683 \\
\hline
\end{tabular}

入することになっているため, 電力自給プロセスのよ うに発電に併う効率の低下が含李れていないためであ ろう。したがって, SRC-II プロセスも, もし電力自 給のプラントであれば，他のプロセスとほとんど効率 は同程度になるものと思われる。

\section{4. 石炭液化生成物の用途を考慮した場合の 最終消費効率}

石炭の直接液化プロセスから得られる生成物の性 状, 製品の種類とその収率は, 主として水素化分解の 深度によって異なる。また石炭の間接液化法から得ら れる生成物の性状および製品は直接液化により得られ るものとはかなり異なる。したがって，それらの得ら れた製品を二次エネルギーとして利用する場合，最終 消費に招洁る利用形態によって用途が限定される。そ れに併って，一次エネルギー（石炭）から，最終消費 に至るエネルギーの変換効率が異なってくる。

Zielinski ${ }^{8}$ は，いくつかの具体的な直接液化法およ び間接液化法のプロセスを取り上げ，それらのプロセ スから得られる製品の最終消費での用途を適当に定め て, 一次エネルギーから最終用途でのエネルギーの消 費に至る一連のエネルギ一の変換効率を求め比較して いる。ここではその一部を紹介する。Zielinski は, 一次エネルギーから二次エネルギーへの変換効率を次 のように定義している。

$$
\eta_{\mathrm{E}}=\frac{\sum_{\mathrm{i}=1}^{\mathrm{n}} \mathrm{Q}_{\mathrm{i}}}{\mathrm{E}_{\mathrm{S}}+\sum_{\mathrm{j}=1}^{\mathrm{m}} \mathrm{E}_{\mathrm{P} j}}
$$

$\mathrm{Q}_{\mathrm{i}}$ は, 変換によって得られる $\mathrm{i}$ 番目の二次エネルギ 一, $\mathrm{E}_{\mathrm{s}}$ は石炭変換プロセスに投入された一次エネルギ 一, $\mathrm{E}_{\mathrm{Pj}}$ 㹥石炭変換プロセスに投入された $\mathrm{j}$ 番目のエ ネルギー源である。な打エネルギ一の単位はいずれも エンタルピーの絶対量である。従って，この効率は熱
力学第一法則に基ついたものであり，以下に定義され る効率も同様である。各 $\mathrm{i}$ 牡よび $\mathrm{j}$ については以下の よらに分類されている。

$$
\begin{array}{llll}
\mathrm{i}=1 & \text { 電力 } & \mathrm{i}=9 & \text { 中間化学製品 } \\
\mathrm{i}=2 & \text { 燃料ガス } & \mathrm{j}=1 & \text { 水素 } \\
\mathrm{i}=3 & \text { 加熱炉用燃料油 } & \mathrm{j}=2 & \text { 酸素 } \\
\mathrm{i}=4 & \text { ディーゼル油 } & \mathrm{j}=3 & \text { 水蒸気 } \\
\mathrm{i}=5 & \text { S R C } & \mathrm{j}=4 & \text { 動力発生源（電 } \\
\mathrm{i}=6 & \text { 合成ガソリン } & & \text { 力, 然料など） } \\
\mathrm{i}=7 & \text { コークス燃料 } & & \\
\mathrm{i}=8 & \text { 熱ェネルギー (水 } & & \\
& \text { 蒸気あるいは温水) } &
\end{array}
$$

また，一次エネルギー変換から 2 次エネルギーの最 終消費に至る変換効率を次のように定義している。

$$
E_{U}=\frac{\sum_{i=1}^{n} \sum_{k=1}^{r} Q_{i} \cdot \rho_{i, k}}{E_{S}+\sum_{j=1}^{m} E_{P j}}=\frac{\sum_{i=1}^{n} E_{U i}}{E_{S}+\sum_{j=1}^{m} E_{P j}}
$$

$\rho_{\mathrm{i}, \mathrm{k}}$ は, 二次エネルギー $\mathrm{i}$ から最終用途 $\mathrm{k}$ への変換 を表わす指標， $E_{U i}$ は二次エネルギー最終消費で有効 に利用された二次エネルギー $\mathrm{i}$ の熱量を表わしてい る。最終用途 $\mathrm{k}$ は以下のように分類されている。

$$
\begin{aligned}
& \mathrm{k}=1 \text { 重工業 } \mathrm{k}=7 \text { 家庭用厨房 } \\
& \mathrm{k}=2 \text { 軽工業 } \mathrm{k}=8 \text { その他の家庭内消費 } \\
& \mathrm{k}=3 \text { 化学工業 } \mathrm{k}=9 \text { 道路輸送 } \\
& \mathrm{k}=4 \text { 農業 } \mathrm{k}=10 \text { 鉄道輸送 } \\
& \mathrm{k}=5 \text { 家庭用加熱 } \mathrm{k}=11 \text { 自動車用然料 } \\
& \mathrm{k}=6 \text { 家庭用照明 } \mathrm{k}=12 \text { 電力工業 }
\end{aligned}
$$

具体的な石炭液化プロセスとして, (1)Gulf SRC-I, (2) P.O.G.O. (3)COED (4) H-Coal (5) $\mathrm{IChPW}$ (ポー ランドで開発中の液化プロセス) (6)Fischer-Tropsch を取り上げ，上記の変換効率の定義式に從い，計算し 比較を行っている。これ以外に, 石炭の直接燃焼によ 
表 11 二次エネルギーの最終消費を考慮した場合の、種々の石炭液化プロセスの効率の比較

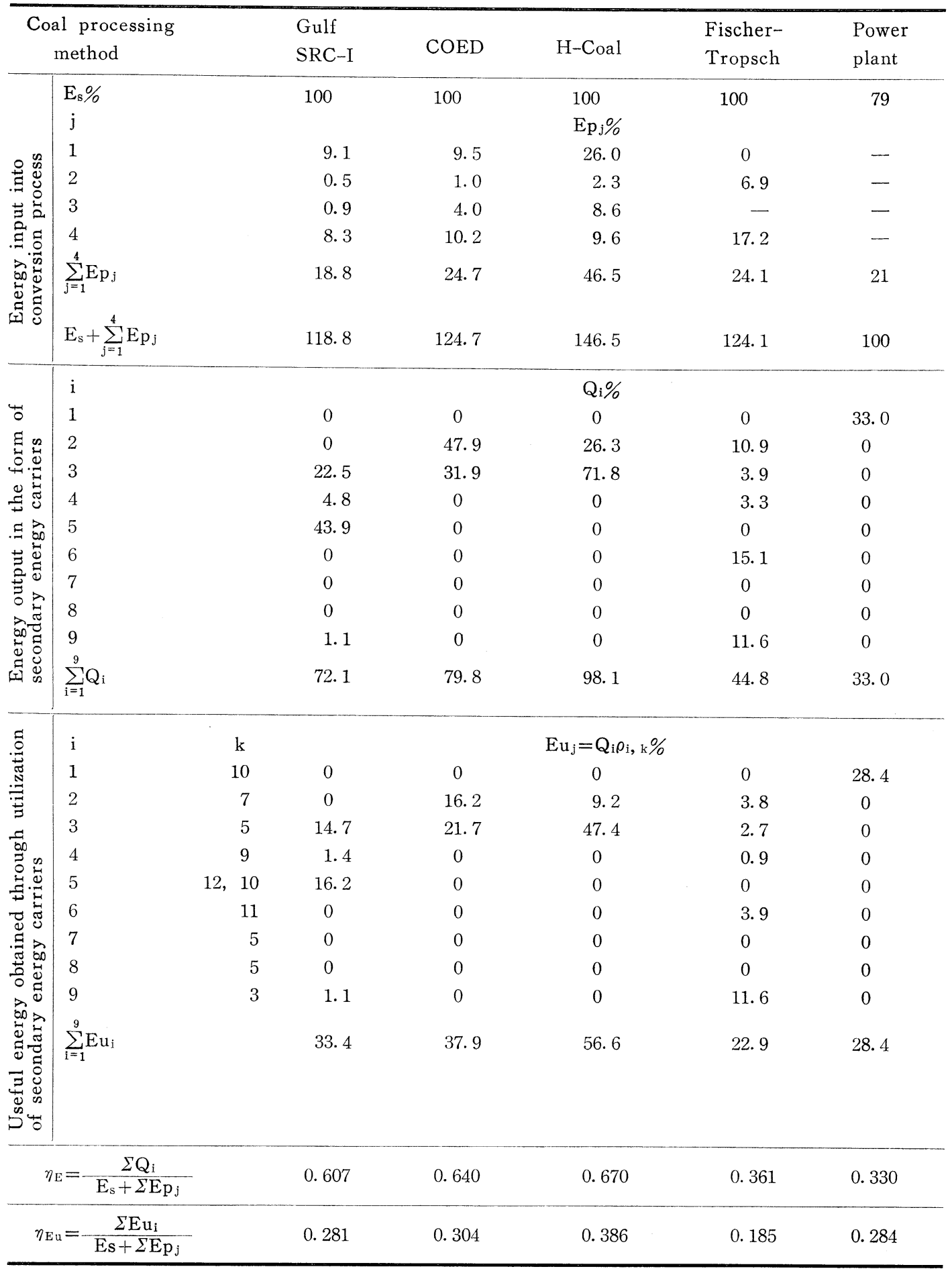


って電気エネルギーを得るケースについても考察して いる。ここではその一部を表11に示す。一次エネルギ 一から二次エネルギーへの変換効率 $\eta_{\mathrm{E}}$ は直接液化プ 口セスの場合0.6〜0.7の間にあることがわかる。これ は, 前章での計算の結果と符合する。これに対して, 間接液化法のFischer-Tropschプロセスは和 $=0.361$ とかなり低い効率であることがわかる。これは F-T プロセスの場合, 石炭をガス化し合成ガスに変換して から炭化水素を合成するという2 段の变換過程を経て いるためである。ただし，間接液化によって得られる 製品は付加価值が高いので, 直接液化法の効率と直接 の比較は妥当ではない。ところで現在直接液化プロ七 スから得られる液化油にさらに水素を添加し, より軽 質の製品を生産するアップグレーディングの技術開発 が進められている。アップグレーディングによって得 られる製品は間接液化によって得られる製品（特にガ ソリン)と性状が類似するものもあるので,一次エネル ギーから最終消費に至る効率の比較も可能となろら。 次回は, この点も含めて解析を試みる予定である。

一次エネルギーから最終消費に至るエネルギーの変 換効率 $\eta_{\mathrm{Eu}}$ は, 直接液化を経由する場合 $0.28 \sim 0.4$ の 間にある。これに対して間接液化経由では 0.185 とか なり低い。この点についても前記の理由で直接比較で きないので, 次回改めて議論する予定である。

\section{文献}

1）石田，西田，燃協誌，61，82 (1982)
2）鈴木, 石田,「原子団寄与法による石炭液化油の 標準生成エンタルピーと絶対ェントロピーの推 算」, 燃協誌, 印刷中

3) Catalytic, Inc., "Preliminary Engineering Evaluation of Promising Coal Liquefaction Concepts”, EPRI Report AF-884 (1979)

4) Fluor Engineers and Constructors, Inc., "Engineering Evaluation of Conceptual Coal Conversion Plant Using the H-Coal Liquefaction Process", EPRI Report AF-1297 (1979)

5) Phillips, E. M., et al., “A Comparative Study of Coal Liquefaction Performance and Economics for Solvent Refined-Based Processes”, 88th AIChE National Meeting, Philadelphia, June (1980)

6）鈴木, 石田, 「原子団寄与法による石炭の標準生 成エンタルピーと絶対エントロピーの推算」, 燃 協誌，61，250 (1982)

7) Unrich, T.L., et al., "The Energetics of the COED Process for Coal Conversion from a Second Law Perspective", 72nd AIChE Annual Meeting, San Francisco, Nov. (1979)

8) Zielinski, H., "Oils and Gases from Coal", Pergamon Press, 73 (1980) 


\title{
Evaluation of Coal Conversion Processes from an Energy Efficient Use Viewpoint (IV)
}

-Energy and Exergy Analysis of Liquefaction Processes-

\author{
Naonori NISHIDA*, Masaru ISHIDA**
}

$\left(\begin{array}{l}* \text { Department of Management Science, Science University of Tokyo } \\ * * \text { Research Laboratory of Resources Utilization, Tokyo Institute of Technology }\end{array}\right)$

SYNOPSIS : - The evaluation of the thermodynamic properties of coal liquids is briefly discussed. A model process of a coal liquefaction is presented and its exergy analysis is developed using "SPEED (Structured Process Energy-Exergy-flow Diagram)". Both the first law and the second law efficiencies of typical over all processes of coal liquefaction are calculated. Processes studied are several SRC-I based ones, SRC-II and H-Coal. The conversion efficiency of coal processing to the useful energy level through several direct coal liquefaction processes and through an indirect coal liquefaction process of Fischer-Tropsch synthesis is reviewed.

\section{Key Words}

Coal liquefaction, Exergy analysis, First law efficiency, Second law efficiency 